\title{
АНАЛІТИЧНИЙ ІНСТРУМЕНТАРІЙ УПРАВЛІННЯ ВИТРАТАМИ ОБІГУ ПІДПРИЄМСТВ ТОРГІВЛІ В УМОВАХ НЕВИЗНАЧЕНОСТІ
}

\author{
ANALYTICAL TOOLS OF TRADE ENTERPRISES' COSTS \\ MANAGEMENT UNDER CONDITIONS OF UNCERTAINTY
}

\author{
Мисака Г. В. \\ кандидат економічних наук, доцент, \\ доцент кафедри обліку та аудиту, \\ Київський національний університет імені Тараса Шевченка, Київ
} ORCID: 0000-0003-0621-8513

\author{
Hanna Mysaka \\ $\mathrm{PhD}$ in Economics, Associate Professor, \\ Department of Accounting and Auditing, \\ Taras Shevchenko National University of Kyiv, Kyiv
}

Статтю присвячено дослідженню ролі економічного аналізу в управлінні витратами обігу на підприємствах торгівлі. Висвітлено значущість перспективного аналізу для планування раціонального витрачання коштів торговельного підприємства. Доведено, що поглиблення аналітичності досліджень зміни показника витрат обігу у часовому розрізі, за структурними підрозділами та статтями не дає можливості комплексно встановити причини абсолютної та відносної економії (перевитрат) і виявити резерви їх скорочення. Обгрунтовано, що виявлення причин, які викликали зміни величини та структури витрат обігу, надає додаткових можливостей при усуненні їх негативного впливу та виявленні суттєвих резервів покращення результатів господарювання Узагальнено систему аналітичних показників, що характеризують витрати обігу; визначено перспективи застосування економіко-математичних методів в аналізі витрат обігу. Ключові слова: бюджетування, витрати обігу, перспективний аналіз, ретроспективний аналіз, фракторний аналіз.

Статья посвящена исследованию роли экономического анализа в управлении издержками обращения на предприятиях торговли. Раскрыта значимость перспективного анализа для планирования рационального расходования средств предприятия. Доказано, что углубление аналитичности исследований изменения показателя издержек обращения во временном разрезе, по структурным подразделениям и статьям не позволяет комплексно установить причины абсолютной и относительной экономии (перерасхода) и выявить резервы их сокращения. Обосновано, что выявление причин, которые вызвали изменения величины и структуры издержек обращения, предоставляет дополнительные возможности при устранении их негативного влияния и выявлении существенных резервов улучшения результатов хозяйствования. Обобщена система аналитических показателей, характеризующих издержки обращения; определены перспективы применения экономико-математических методов в анализе издержек обращения. Ключевые слова: бюджетирование, издержки обращения, перспективный анализ, ретроспективный анализ, фракторный анализ.

This article is devoted to the research of economical analysis ' part in the distribution costs' management at retail enterprises. Since increase of distribution costs normally should provide an outstripping growth of trade turnover, the analysis significance for the rational expenditure is considered. It is proved that the deepening of analytical studies of changes in the indicator of distribution costs in time, by structural divisions and cost items does not allow to comprehensively establish the reasons for the absolute and relative savings (cost overruns) and identify reserves for their reduction. A stable trend towards a decrease in the level and quality of analytical work at retail trade enterprises was revealed, which is associated with insufficient labor resources for its implementation and the lack of external regulation of planning processes and analysis of economic performance indicators, including distribution costs. It has been substantiated that identifying the reasons that caused changes in the size and structure of distribution costs provides additional opportunities for eliminating their negative impact and identifying significant reserves for improving business results. Prompt identification and use of reserves to reduce turnover costs requires the use of economic and mathematical methods of analysis in combination with promising methods of commercial budgeting. The complexity of the calculations will be partially offset by an in-depth scientific substantiation of the results, and the availability of wide practical application can be achieved by standardizing the methodology of thematic analysis of distribution costs. The system of distribution costs' analytic indices of is generalized; the perspective application of economic-mathematical methods is determined in analysis of distribution costs. Key words: budgeting, distribution costs, prospective analysis, retrospective analysis, factor analysis. 
Постановка проблеми. Успішне розв'язання комплексу найважливіших завдань, що постають перед будь-яким підприємством (у тому числі і торговельним) в умовах вільного ринку та конкуренції, досягається за допомогою раціонального управління. В процесі ведення фрінансово-господарської діяльності з метою отримання прибутку суб'єкти господарювання стикаються з необхідністю розв'язувати низку завдань виробничого і соціального характеру, зокрема: збільшення обсягів виробництва та реалізації продукції, товарів, робіт, послуг; оптимізація і скорочення витрат діяльності; підвищення рентабельності здійснюваних проєктів; соціальний захист працівників тощо. Важливу роль в пошуку актуальних та ефрективних способів оптимізації управління торговельним підприємством відіграє економічний аналіз.

Аналіз останніх досліджень і публікацій. Логіка послідовного аналізу витрат обігу викликала фрормування традиційної схеми його проведення у декілька взаємопов'язаних етапів. При здійсненні ретроспективного аналізу витрат обігу спочатку аналізується виконання плану (кошторису, бюджету) та динаміка витрат загалом по підприємству та у розрізі його структурних підрозділів за умов наявності достовірної аналітичної інформації. Зміст наступного етапу аналізу полягає у визначенні та вимірюванні впливу на витрати обігу окремих фракторів. На третьому, завершальному етапі проводиться аналіз витрат обігу у розрізі окремих видів (статей номенклатури) $з$ додатковим дослідженням індивідуального факторного впливу на конкретні статті витрат обігу торговельних підприємств. Тобто у ретроспективі витрати обігу аналізуються на дедукційній основі. Зазначений підхід до формування методики аналізу витрат обігу пропонується такими відомими фахівцями як М. С. Абрютіна [1], М. І. Баканов [3], Л. І. Кравченко [8], В. С. Рудницький [11], М. Г. Чумаченко [6] та іншими.

Однак таке розчленування досліджуваних показників витрат, на нашу думку, не може бути завершальною стадією проведення аналізу витрат обігу; навпаки, воно є передумовою правильного виявлення та тлумачення економічної сутності об'єктів у всьому спектрі їх взаємозв'язків та взаємозалежностей з іншими економічними показниками, що склалися в процесі фрінансово-господарської діяльності торговельного підприємства.

На підставі проведеного вивчення результатів останніх наукових досліджень та публікацій $[2,4,7]$, присвячених питанням економічного аналізу витрат обігу торговельних підприємств, можна сформувати узагальнену методику проведення ретроспективного аналізу витрат обігу, яка має наступну послідовність проведення:

1) визначення абсолютних відхилень фрактич- них витрат обігу звітного періоду від планових показників (якщо такі $є$ ) та від фактичних величин минулих періодів (за умови забезпечення порівнювання даних) за такими аналітичними напрямами:

- загальними сумами за рік по підприємству;

- за кварталами та місяцями по підприємству;

- у розрізі структурних підрозділів підприємства загалом за рік, по кварталах та місяцях;

- за статтями (видами) витрат;

2) розрахунок рівня витрат обігу за підприємством і його структурними підрозділами за рік, квартал, місяць та видами витрат;

3) встановлення величини зміни розрахованого рівня витрат;

4) визначення темпів зміни витрат обігу за сумою та рівнем;

5) розрахунок питомої ваги кожної статті витрат обігу у їх загальній величині;

6) визначення суми відносної економії (перевитрат) витрат обігу.

На підставі одержаних аналітичних показників, що характеризують загальні тенденції поведінки витрат обігу у звітному періоді, зазвичай в практиці діяльності планово-економічних і аналітичних служб торговельних підприємств робляться висновки та дається оцінка виявленим змінам [9,12]. Проте навіть поглиблення аналітичності досліджень у часовому розрізі, за структурними підрозділами та видами (статтями) витрат обігу не дає можливості обґрунтовано визначити причини абсолютної та відносної економії (перевитрат) і виявити резерви їх скорочення. Для цього потрібно дослідити сукупність чинників, що прямо або опосередковано вплинули на поведінку витрат обігу, визначити та виміряти характер кожного з найсуттєвіших факторів індивідуально $[5,10]$. Обґрунтоване визначення та диференціація причин, що викликали зміни величини та структури витрат обігу, надає додаткових можливостей при усуненні їх негативного впливу та виявленні суттєвих резервів покращення результатів господарювання.

Формулювання цілей статті (постановка завдання). Першочерговими завданнями, вирішенню яких присвячено дану статтю, є: дослідження ролі та значення економічного аналізу в управлінні витратами обігу торговельних підприємств, встановлення пріоритетних напрямів його розвитку у цій ссрері; ознайомлення з практичним станом речей в організації та веденні аналітичної роботи на підприємствах торгівлі, визначення перспективних шляхів ії удосконалення; дослідження методології економічного аналізу на предмет ії відповідності сучасним вимогам управління та ефективності застосування найпоширеніших методів у перспективному аналізі та плануванні витрат обігу, оцінка потенціалу ви- 
користання економіко-математичних прийомів і способів в удосконаленні методики економічного аналізу витрат обігу.

Виклад основного матеріалу дослідження. Діалектичний підхід до вивчення процесів господарської діяльності передбачає дослідження взаємозв'язків та взаємозалежностей їх становлення та розвитку на будь-якому рівні господарювання. Дотримання даної умови є першоосновою ефективного економіко-аналітичного дослідження причин, що викликали зміни заданих показників, вивчення економічної природи виокремлених чинників, вплив яких можна кількісно вимірити, визначення прихованих резервів підвищення ефективності фрінансово-господарської діяльності і розробки оптимальних управлінських рішень, спрямованих на якнайповніше використання виявлених резервів.

Для забезпечення оптимального вибору та обґрунтування управлінських рішень за складних умов формування ринкових відносин необхідно розглядати підприємство та його діяльність як упорядковану сукупність взаємопов'язаних та взаємодіючих елементів, тобто як систему. Системний підхід як загальнонаукова методологічна концепція пізнання розширює можливості економічного аналізу в процесі дослідження його об'єктів. Розглядаючи власні об'єкти дослідження як системи взаємопов'язаних елементів, економічний аналіз одержує додаткові можливості для формування структурної моделі досліджуваного економічного процесу, явища або категорії та застосування економіко-математичних прийомів та способів їх дослідження. Системність економічного аналізу означає, в першу чергу, всебічне дослідження причин, які викликали зміни тих або інших показників діяльності торговельного підприємства, та встановлення щільності зв'язку між цими показниками і фракторами, що на них впливають. Використання математичних методів для розв'язання проблем економічного аналізу сприяє обґрунтованості прийнятих управлінських рішень завдяки високій надійності та точності результатів математичних розрахунків, на які вплив суб'єктивізму відповідального виконавця зведено до мінімуму.

Сутність економічного аналізу як складової частини економічних методів управління торговельним підприємством обумовлюється об'єктивною потребою організації господарської діяльності відповідно до вимог економічних законів ринку. Організацію аналітичної роботи управлінським апаратом підприємства роздрібної торгівлі доцільно здійснювати відповідно до науково обґрунтованої класифікації видів економічного аналізу. Зважаючи на необхідність широкого використання економічного аналізу в процесі складання стратегічних та поточних планів фінансово-господарської діяльності підприємств, під час оцінки виконання запланованих показників, підведенні підсумків результатів роботи за визначений період та при виявленні шляхів підвищення ефективності господарювання, серед яких чільне місце займають пошуки резервів скорочення та оптимізації витрат, виділяють три наступні види економічного аналізу: перспективний, поточний (оперативний) та ретроспективний.

3 метою якісної реалізації таких функцій управління як планування і прогнозування діяльності використовується перспективний аналіз. Характерною рисою перспективного аналізу $\epsilon$ дослідження процесів та явищ фрінансово-господарської діяльності з позицій перспективи розвитку підприємства. Етап попереднього управління, на якому використовується перспективний аналіз, вирізняється складністю і трудомісткістю здійснюваних заходів з планування і прогнозування, оскільки наукове обґрунтування перспективних планів базується на дослідженні фрактів з теперішнього і минулого підприємства та виявленні стабільних тенденцій зміни економічних показників господарської діяльності у динаміці $[2,9,12]$. Ґрунтуючись на вивченні закономірностей розвитку різноманітних економічних явищ та процесів підприємницької діяльності торговельного підприємства, господарське прогнозування встановлює найперспективніші шляхи його розвитку і фрормує базу для вибору та обґрунтування планових завдань на будь-якому рівні управління. Таким чином, функції економічного прогнозування $€$ виключно аналітичними.

Завдання перспективного аналізу зумовлюються його сутністю, характерними особливостями, роллю в процесах управління торговельним підприємством та планування його діяльності. Виходячи з цього, найважливішими завданнями виступають:

1) прогнозування змін у внутрішньому та зовнішньому середовищах торговельного підприємства;

2) наукове обґрунтування перспективних планів господарської діяльності на основі дослідження даних за декілька років;

3) планування найважливіших показників фінансово-господарської діяльності за різних, проте майже однаково ймовірних за досягненням обсягів виробництва (реалізації) або рівнів потужності підприємства;

4) оцінка очікуваного виконання планів;

5) комплексне дослідження фракторного впливу на заплановані показники діяльності $[6,11]$.

Головною метою перспективного аналізу витрат обігу $€$ обґрунтоване визначення мінімальних витрат, які б забезпечували нормальне функціонування підприємства роздрібної торгів- 
лі, реалізацію поточних та стратегічних планів розвитку фірми, зокрема, обсягу товарообороту і прибутку та підвищення якості торговельного обслуговування.

Методика перспективного аналізу та планування витрат обігу базується на ретельному дослідженні фактичних даних про основні показники фінансово-господарської діяльності підприємства роздрібної торгівлі (товарооборот, товарні запаси, доходи від реалізації, чисельність працюючих, витрати та прибуток за даними бухгалтерського і податкового обліку, торговельна площа тощо) та витрати у розрізі статей номенклатури, що використовується на підприємстві, за минулий період. В умовах розвитку ринкових відносин змінюється призначення калькуляції собівартості послуг торговельних підприємств і організацій, яка набуває фрорми та змісту інструменту аналізу витрат обігу, фінансових результатів діяльності суб'єктів господарювання, що функціонують у сфері торгівлі, та стає засобом підвищення на цій основі ефрективності їх роботи.

Перспективний аналіз витрат обігу в практичній діяльності обліково-аналітичних служб торговельних підприємств посідає ледь не найостанніше місце і використовується тільки під час завершальної стадії ретроспективного аналізу як частина узагальнення результатів останнього у вигляді переважно емпіричних прогнозів. Водночас можна спостерігати стабільну тенденцію до розширення ролі перспективного аналізу в торгівлі - із збільшенням розміру підприємства зростає потреба у обґрунтованому плануванні його діяльності.

Передумовою економічно обґрунтованого перспективного аналізу як основи планування витрат обігу виступає облік та всебічний аналіз витрат у звітному періоді. Слід зазначити, що паралельно з традиційними плануванням в практику управління фрінансово-господарською діяльністю вітчизняних підприємств поступово впроваджується комерційне бюджетування як більш сучасний, удосконалений інструмент системної організації господарювання. На відміну від статичних показників планування, якими описується лише один рівень активності (потужності) підприємства, гнучкі бюджети пропонують дані, що характеризують найвірогідніший діапазон активності суб'єкта господарювання на наступний період.

Головна перевага комерційного бюджетування полягає у створенні додаткових можливостей контролю за витратами шляхом складання гнучких бюджетів. В основі гнучкого бюджетування лежить диференціація витрат на постійні та змінні, дозволяючи автоматично налаштовувати бюджет до того рівня активності, який фактично має місце у звітному періоді. Вимірювання відхилень фактично здійснених змінних витрат від їх запланованої величини проводиться у відповідності із встановленими змінами (збільшенням або зменшенням) обсягу товарообороту до того, як буде розраховано відхилення, викликані факторами ціни та структури реалізації. «Основне застосування гнучкого бюджету полягає в точному вимірюванні виконаних робіт за допомогою порівняння фактичних витрат з плановими відповідно бюджету для одного і того самого рівня виходу. 3 точки зору контролю немає сенсу порівнювати витрати, здійснені при різних рівнях активності.» [13, с. 93-94]

Таким чином, гнучке бюджетування забезпечує додержання основної передумови ефективного проведення аналізу та контролю витрат обігу в процесі порівняння планових даних 3 фактичними - їх зіставляння.

Планування i прогнозування витрат обігу 3 використанням елементів перспективного аналізу здійснюється на основі даних періодичного (ретроспективного) аналізу найчастіше у зворотному порядку: спочатку плануються показники окремих видів витрат, а потім, шляхом їх узагальнення, виводиться очікувана величина витрат обігу на наступний період. В процесі взаємоув'язки планових показників загальна сума витрат обігу може зазнавати певних коригувань. Виявлені під час проведення ретроспективного аналізу фактори, закономірності та тенденції, що вплинули на зміну витрат обігу в базисному періоді, необхідно дослідити на предмет можливого їх впливу в періоді, на який складається план.

За характером залежності від діяльності торговельного підприємства усю сукупність чинників умовно поділяють на:

1) внутрішні (суб'єктивні) - такі, що залежать від якості роботи підприємства та рівня його управління;

2) зовнішні (об'єктивні) - такі, що є наслідком політичних, економічних і соціальних процесів у зовнішньому щодо підприємства середовищі.

Зовнішні фактори досить легко виявляються та виокремлюються, їх вплив нескладно виміряти та дослідити, в першу чергу, завдяки їх очевидності (публікації в пресі про зміни державної податкової політики, механізму ціноутворення тощо, офіційні повідомлення від контрагентів про зміни ставок, тарифів і т.п.). Проте усунення негативних наслідків їх дії $€$ практично недосяжним для управлінського апарату торговельного підприємства. Виявлення дії суб'єктивних чинників $є$ більш складним процесом, який потребує, крім знань аналізу, найдетальнішої обізнаності із специфічними нюансами організації фрінансово-господарської діяльності на даному торговельному підприємстві [5]. 
Розрахунок впливу фракторів, що викликають зміни витрат обігу, здійснюється з використанням економіко-логічних та економіко-математичних прийомів і способів аналізу. Вибір та правильність застосування конкретного прийому залежить від характеристики існуючого між досліджуваними показниками зв'язку [2]. Наявність функціонального зв'язку між витратами та певними чинниками їх змін дозволяє вимірювати вартість такого впливу прийомами елімінування, серед яких найпоширенішими є прийом ланцюгових підстановок, спосіб абсолютних та відносних різниць, сальдовий прийом тощо.

Відсутність між економічними показниками суворої функціональної залежності спонукає використовувати кореляційно-регресійний метод аналізу, до можливостей якого входить обґрунтування наявності та визначення фрорми зв'язку між ними. Застосування даного методу дозволяє розв'язати два завдання. По-перше, встановити щільність зв'язку між показниками, що досліджуються; по-друге, дослідити характер зв'язку та провести кількісне вимірювання дії фрактора, вплив якого аналізується, на витрати обігу. Форма зв'язку між показниками визначається на основі попередніх аналітичних розрахунків та додатково обґрунтовується у графрічному вигляді [8, с. 26-27].

Графрічний метод відображення зв'язку між декількома економічними показниками дає можливість унаочнити виявлені під час фракторного аналізу характерні тенденції впливу на результатний показник обраних чинників. При цьому можна застосовувати різні види графрічних зображень - лінійні (для демонстрації однофракторної моделі залежності), деревоподібні графи та діаграми (при узагальненні впливу кількох факторів на результатний показник).

Враховуючи відносну економічну нестабільність в Україні (інфляційні процеси, зміни видів та ставок відрахувань на соціальні заходи, зміни тарифів на комунальні послуги тощо) та можливі організаційно-структурні перетворення всередині власне підприємства торгівлі протягом обстежуваного періоду діяльності, при проведенні аналітичних розрахунків з використанням інформації про величину витрат обігу та обсяги роздрібного товарообороту необхідно здійснити комплекс підготовчих заходів, які б мали забезпечити порівнюваність даних, що аналізуватимуться, за методами оцінки, методикою розрахунку, структурі, календарних термінах, умовах роботи організації тощо. Зокрема, необхідно перерахувати показники обсягів реалізації та витрат обігу (загалом і в розрізі окремих видів, статей) 3 використанням офріційно оголошених щорічних темпів інфляції, виявити фрактори, що мали кардинальний вплив на витрати обігу, зміну їх скла- ду і структури, проаналізувати та по можливості ізолювати викликані ними зрушення тощо.

Витрати обігу завжди вважалися якісним показником торгівлі, оскільки їх збільшення має забезпечувати випереджаючий ріст обсягу товарообороту. Тому головний критерій оцінки витрат - рівень - має відносну природу формування. Загалом витрати обігу характеризуються наступною системою показників (табл. 1).

Значний вплив на зміну витрат обігу чинять зміни складу та структури роздрібного товарообороту. Відомо, що реалізація продовольчих товарів $є$ більш витратоємною, аніж торгівля товарами непродовольчого асортиментного переліку. Так, Л.І.Кравченко наводить наступне співвідношення: «підраховано, що реалізація на одну й ту саму суму продовольчих товарів потребує майже удвічі більше витрат, аніж непродовольчих» [8, с. 157]. Тому, якщо торговельне підприємство не має чітко вираженого профілю, то треба мати на увазі, що зростання на 1\% питомої ваги реалізації продовольчих товарів у загальному обсязі роздрібного продажу автоматично призводить до підвищення загального рівня витрат обігу на 0,03-0,04\% до товарообороту. Одночасно відносне збільшення обсягу реалізації непродовольчих товарів стимулює скорочення відносного рівня витрат обігу на ту саму величину.

Теоретично поглиблення аналізу витрат обігу в розрізі структурних складових роздрібного товарообороту може здійснюватися у напрямку товарних груп або окремих товарів. Але на практиці це вимагає підвищення аналітичності обліку витрат, що супроводжується ускладненням його організації та ведення [4,7]. Тому вимірювання впливу зміни структури товарообороту на витрати обігу можна проводити прийомом різниць з використанням способу процентних чисел. Однак ця методика передбачає планування потоварних рівнів витрат обігу, що, в свою чергу, неможливо зробити без якісної організації та ведення аналітичного обліку витрат обігу за товарними групами.

Загалом, слід зазначити, що аналіз впливу структури товарообороту на витрати обігу торговельного підприємства на практиці майже не проводиться. Дана ситуація обумовлена складністю формування облікової інфрормації про витрати у розрізі товарних груп та громіздкістю застосовуваних методик. Для встановлення планових рівнів потоварної витратоємності, крім вищезазначеного способу організації та ведення аналітичного обліку витрат обігу у розрізі окремих товарних груп, пропонувалося використовувати способи, що ґрунтуються на аналізі потоварних рівнів торговельних націнок та даних про витрати обігу спеціалізованої торговельної мережі [8]. Кожен з цих способів мав певні недоліки 
Система аналітичних показників, що використовуються для аналізу виконання кошторису (плану) та динаміки витрат обігу в торгівлі

\begin{tabular}{|c|c|c|}
\hline $\begin{array}{l}\text { Найменування } \\
\text { показника }\end{array}$ & Алгоритм розрахунку & Умовні позначення \\
\hline $\begin{array}{l}\text { 1. Рівень витрат обігу } \\
\text { (у відсотках) }\end{array}$ & $P e O=\frac{\sum B O}{T O} * 100 \%$ & $\begin{array}{l}P_{60-\text { рівень витрат обігу }} \\
\Sigma B O \text { - сума витрат обігу } \\
T O_{\text {- обсяг товарообороту }}\end{array}$ \\
\hline $\begin{array}{l}\text { 2. Абсолютне відхи- } \\
\text { лення по сумі (еконо- } \\
\text { мія або перевитрати) }\end{array}$ & $\Delta B O=B O_{1}-B O_{0}$ & $\begin{array}{c}\triangle B O \text { - абсолютне відхилення витрат обігу по } \\
\text { сумі } \\
B O_{1,0-\text { величина витрат обігу звітного і базис- }} \\
\text { ного (планового) періодів }\end{array}$ \\
\hline $\begin{array}{l}\text { 3. Розмір зміни (зни- } \\
\text { ження або підвищення) } \\
\text { рівня витрат }\end{array}$ & $\triangle P B O=P_{B O}-P_{1} O_{0}$ & 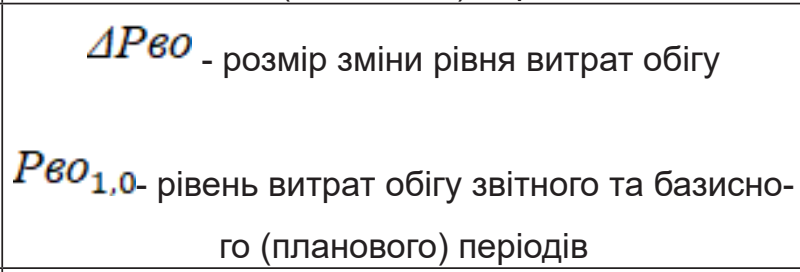 \\
\hline $\begin{array}{l}\text { 4. Темп зміни суми } \\
\text { витрат обігу }\end{array}$ & $T_{B O}=\frac{B O_{1}}{B O_{\mathrm{n}}} * 100 \%$ & $T_{B O}$ - темп зміни витрат за сумою \\
\hline $\begin{array}{l}\text { 5. Темп зміни рівня } \\
\text { витрат обігу }\end{array}$ & $T_{P_{\varepsilon o}}=\frac{\Delta P \varepsilon O}{P B O_{0}} * 100 \%$ & $T_{P \varepsilon o-\text { темп зміни витрат за рівнем }}$ \\
\hline $\begin{array}{c}\text { 6. Сума відносної } \\
\text { економії (перевитрат) } \\
\text { витрат обігу * }\end{array}$ & $\Delta \sum \theta_{(\text {бідे.) }}=\frac{T O_{1} * \Delta P_{\epsilon O}}{100 \%}$ & $\begin{array}{c}T O_{1-\text { величина фрактичного обсягу товарообо- }} \\
\text { роту за звітний період }\end{array}$ \\
\hline $\begin{array}{l}\text { 7. Питома вага окремої } \\
\text { статті витрат обігу в їх } \\
\text { загальній сумі }{ }^{* *}\end{array}$ & $d_{i}=\frac{B O_{i}}{B O_{3 A \Gamma}} * 100 \%$ & $\begin{array}{c}d_{i-\text { питома вага окремої статті витрат в їх за- }} \\
\text { гальній сумі } \\
B O_{I, 3 A T-\text { розмір окремої статті та загальна }} \\
\text { величина витрат обігу }\end{array}$ \\
\hline $\begin{array}{l}\text { 8. Витратомісткість ре-- } \\
\text { алізації товарної групи } \\
\text { (окремого товару) } \\
\text { (Потоварний рівень } \\
\text { витрат обігу) }\end{array}$ & BMmoe $_{i}=\frac{\text { BOmoe }_{i}}{\text { TOmoe }_{i}} * 100 \%$ & 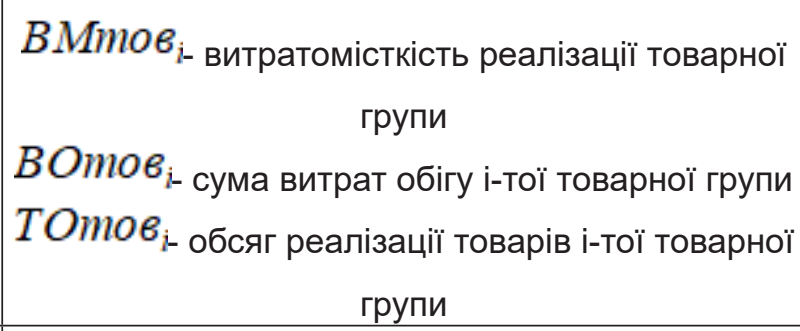 \\
\hline 9. Витратовіддача & $B B=\frac{T O}{B O}$ & $B B_{- \text {витратовіддача }}$ \\
\hline
\end{tabular}

* Також використовується альтернативна методика розрахунку розміру відносної економії (перевитрат) витрат обігу:

$$
\Delta \Sigma e O_{(\text {відн.) }}=\Sigma e O_{\text {факт }}-\Sigma e O_{\text {nлан, }}^{/}
$$

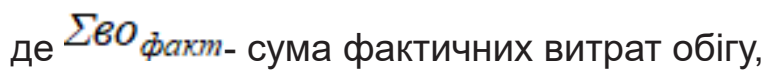

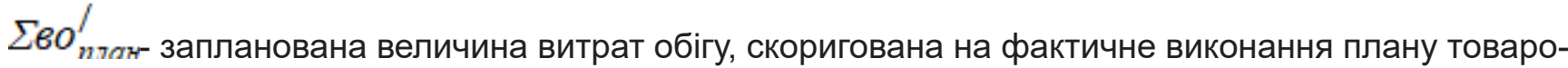
обороту.

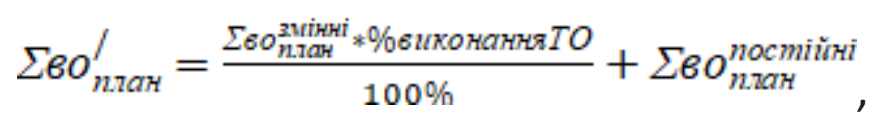

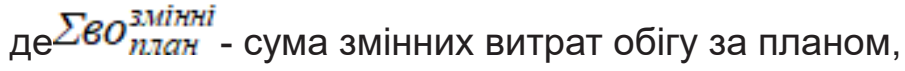


\% виконання ТО - відсоток виконання товарообороту порівняно з планом,

$\sum 8 o_{\text {nлан }}^{\text {nостій }}$

** Аналогічно розраховується питома вага витрат обігу за кварталами або місяцями відповідного періоду.

Джерело: систематизовано автором за [1,3,8,11]

ще за часів їх розробки. За сучасних, принципово нових умов господарювання дані способи стали практично неприйнятними.

Спосіб вимірювання впливу змін структури роздрібної реалізації на витрати обігу виходячи з потоварних рівнів торговельних націнок в своїй основі має теоретично обґрунтоване припущення, що рівні торговельних націнок за окремими товарами встановлюються виходячи з їх витратоємності. Зараз же головним критерієм при визначенні торговельними підприємствами націнки виступає ймовірність досить швидкого продажу товару за даної роздрібної ціни та забезпечення прибутковості діяльності фрірми. Тобто процес встановлення ціни реалізації товарів досить часто носить зворотній характер: спочатку визначають обґрунтовану за теперішньої ринкової кон'юнктури продажну ціну, а вже потім обчислюють рівень націнки, виходячи з вартості придбання товару.

Інший спосіб визначення впливу змін структури роздрібної реалізації на витрати обігу, що базується на використанні звітних даних спеціалізованої торговельної мережі, має два суттєві недоліки, які роблять недоцільним його застосування. По-перше, потоварні рівні витрат обігу спеціалізованих підприємств торгівлі $€$ значно нижчими, ніж у неспеціалізованих [3, с.160]; а по-друге, відсутність системи адміністративного централізованого управління торговельною галуззю і функціонування в даній сфері підприємств переважно приватної та колективної фрорм власності, які розглядають детальну інформацію про свої витрати як комерційну таємницю, унеможливлює отримання достовірних показників рівнів витрат обігу за окремими товарними групами з використанням даного підходу. Крім того, вузька спеціалізація торговельних підприємств в умовах переходу до ринкових відносин може стати причиною банкрутства через суттєві зміни кон'юнктури ринку. Тому сьогодні спостерігається стабільна тенденція до створення підприємств торгівлі з мультитоварним асортиментом, причому часто змішаного продовольчо-промислового характеру.

Крім вищезазначеної методики вимірювання впливу зміни структури товарообороту на витрати обігу з використанням прийому різниць та способу процентних чисел для вирішення цієї проблеми використовувалася методика вибіркового потоварного обліку витрат обігу торговельних підприємств та методику розподілу витрат між товарними групами за допомогою коефіцієнтів їх порівнюваної витратоємності. Обидві методики $€$ досить складними для широкого практичного застосування на підприємствах роздрібної торгівлі, особливо дрібних та середніх, викликають створення додаткового навантаження на праців- ників обліково-аналітичного апарату як в процесі збирання інформації про витрати у специфічному потоварно-груповому розрізі, так і під час розрахунків. 3 науково-теоретичної точки зору ці методики обтяжені низкою умовностей, одержані з їх використанням результати мають суттєву похибку, тому на сучасному етапі розвитку економічного аналізу в торгівлі $є$ малоперспективними.

Аналіз абсолютних відхилень витрат обігу від їх планової величини або відповідних показників попереднього (базисного) періоду не дає можливості правильно оцінити характер впливу встановлених змін на загальну картину господарської діяльності торговельного підприємства. Використовуваний в промисловості метод «затрати-випуск» дозволяє визначити кінцевий результат і полягає в обчисленні фрінансового результату шляхом співставлення витрат з випуском. В торгівлі показником, що характеризує потужність підприємства та інтенсивність його діяльності виступає обсяг товарообороту. Тому понесені або заплановані витрати для адекватної оцінки їх величини необхідно в першу чергу співставити із відповідним обсягом реалізації, визначивши таким чином співвідношення «затрати-випуск» для торговельних підприємств. Рівень витрат обігу також демонструє питому вагу, що її займають витрати в роздрібній вартості товарів.

Висновки. Підсумовуючи вищевикладене, можна зробити висновок, що процеси організації та проведення економічного аналізу витрат обігу торговельними підприємствами мають значну науково-теоретичну основу у вигляді обґрунтованої диференціації видів аналізу стосовно часу проведення і поставлених завдань та великої кількості альтернативних методик дослідження окремих аспектів поведінки витрат. Водночас в процесі здійснених досліджень виявлено стабільну тенденцію до зниження рівня та якості аналітичної роботи на підприємствах роздрібної торгівлі, що пов'язано із недостатністю ресурсів для її проведення (у першу чергу трудових) та відсутністю звичної зовнішньої регламентації процесів планування і аналізу економічних показників діяльності, у тому числі й витрат обігу. Виправити становище, що склалося, можна, на нашу думку, в першу чергу, шляхом підвищення рівня справдження запланованих показників та оперативного виявлення і використання резервів скорочення витрат обігу. Для цього необхідно застосувати потенціал економіко-математичних методів аналізу у поєднанні 3 перспективними методиками комерційного бюджетування. Складність розрахунків частково компенсуватиметься поглибленим науковим обґрунтуванням результатів, а доступність широкого практичного застосування можна досягти стандартизацією методики тематичного аналізу витрат обігу. 


\section{БІБЛІОГРАФІЧНИЙ СПИСОК:}

1. Абрютина М.С. Экономический анализ торговой деятельности. М.: Дело и Сервис. 2000. 512 с.

2. Антипіна О. В., Неділько А. А., Скорін Ю. І. Порівняльний аналіз сучасних методів прогнозування економічних показників торгівельного підприємства. Системи обробки інформації. 2020. №. 1 (160). С. $26-31$. https://doi.org/10.30748/soi.2020.160.03.

3. Баканов М.И. Анализ хозяйственной деятельности в торговле. М.: Экономика, 1999. 350 с.

4. Бортнікова Н. Вплив структури товарообігу підприємства на витрати обігу. Економічний аналіз. 2009. №. 4. C. 171-176. URL:http://dspace.wunu.edu.ua/bitstream/316497/265/1Економічний\%20аналіз\%202009\%20-4_1. pdf\#page=171 (дата звернення: 17.07.2021)

5. Гринів Б., Гринів В. Проблеми фракторного аналізу витрат обігу підприємств роздрібної торгівлі. Економічний аналіз. 2012. №.10 (3). С. 258-261.

6. Економічний аналіз: Навч. посібник / За ред. М.Г. Чумаченка. К.: КНЕУ, 2001. 540 с.

7. Коцеруба Н. В., Лагдан А. В. Аналіз реалізації товарів та витрат підприємств роздрібної торгівлі. Вісник Хмельницького національного університету. Економічні науки. 2017. №. 1. С. 65-69.

8. Кравченко Л.И. Анализ хозяйственной деятельности в торговле. Минск: Вышэйшая школа, 1995. 403 с.

9. Лугівська О. П., Лугівська Л. А. Особливості управління витратами обігу торговельного підприємства в умовах трансформаційних процесів. Науковий вісник PUET: Economic Sciences. 2021. №. 4 (66). C. 54-59. URL:http://www.journal.puet.edu.ua/index.php/nven/article/view/1738 (дата звернення: 21.07.2021)

10. Півнюк О. П. Фактори, що визначають обсяг і структуру витрат обігу на підприємстві. Науковий вісник Полтавського університету економіки і торгівлі. Серія: Економічні науки. 2010. №. 2. С. 197-200.

11. Рудницький В.С. Організація первинного обліку та економічного аналізу на прикладі підприємств торгівлі. К.: ЦУЛ. 2004. 480 с.

12. Ткаченко С. О. Вдосконалення системи оптимізації витрат обігу. Проблеми економіки. 2012. №. 1. С. 91-95. URL:https://www.problecon.com/export_pdf/problems-of-economy-2012-1_0-pages-91_95.pdf (дата звернення: 02.08.2021)

13. Шим, Джей К., Сигел, Джоэл Г. Методы управления стоимостью и анализа затрат. М.: Информ.-изд. дом “Филинъ”, 1996. 344 с.

\section{REFERENCES:}

1. Abryutina, M. S. (2000). Ekonomicheskij analiz torgovoj deyatel'nosti. [Economic analysis of trade activity]. Moscow: Delo i Servis. [in Russian].

2. Antypina, O. V., Nedilko, A. A., \& Skorin, Yu. I. (2020). Porivnialnyi analiz suchasnykh metodiv prohnozuvannia ekonomichnykh pokaznykiv torhivelnoho pidpryiemstva [Comparative analysis of modern methods of forecasting economic indicators of a trade enterprise]. Systemy obrobky informatsii - Information processing systems, 1(160), 26-31. https://doi.org/10.30748/soi.2020.160.03 [in Ukrainian].

3. Bakanov, M. I. (1999). Analiz hozyajstvennoj deyatel'nosti v torgovle. [Analysis of economic activity in trade]. Moscow: Ekonomika. [in Russian].

4. Bortnikova, N. (2009). Vplyv struktury tovaroobihu pidpryiemstva na vytraty obihu [The influence of the structure of the enterprise turnover on the distribution costs]. Ekonomichnyi analiz - Economic analysis, 4, 171-176. [in Ukrainian]. URL:http://dspace.wunu.edu.ua/bitstream/316497/265/1Економічний\%20аналіз\%202009\%20-4_1. pdf\#page=171 (accessed 17 July 2021).

5. Hryniv, B. \& Hryniv, V. (2012). Problemy faktornoho analizu vytrat obihu pidpryiemstv rozdribnoi torhivli [Problems of factor analysis of distribution costs of retail enterprises]. Ekonomichnyi analiz - Economic analysis, 10(3), 258-261. [in Ukrainian].

6. Chumachenko, M. G. (Ed.). (2001). Ekonomichnyi analiz: Navch. Posibnyk. [Economic analysis: Tutorial]. Kyiv: KNEU. [in Ukrainian].

7 Kotseruba, N. V. \& Lahdan, A. V. (2017). Analiz realizatsii tovariv ta vytrat pidpryiemstv rozdribnoi torhivli. [Analysis of sales of goods and costs of retail]. Visnyk Khmelnytskoho natsionalnoho universytetu. Ekonomichni nauky - Visnyk of Khmelnytsky National University. Economic sciences, 1, 65-69. [in Ukrainian].

8. Kravchenko, L. I. (1995). Analiz hozyajstvennoj deyatel'nosti v torgovle. [Analysis of economic activity in trade]. Minsk: Vyshejshaya shkola [in Russian]

9. Luhivska, O. P. \& Luhivska, L. A. (2021). Osoblyvosti upravlinnia vytratamy obihu torhovelnoho pidpryiemstva v umovakh transformatsiinykh protsesiv. [Features of cost management of a trade enterprise in terms of transformation processes. Naukovyi visnyk PUET: Economic Sciences - Scientific Bulletin PUET: Economic Sciences, 4(66), 5459. [in Ukrainian]. URL:http://www.journal.puet.edu.ua/index.php/nven/article/view/1738 (accessed 21 July 2021).

10. Pivniuk, O. P. (2010). Faktory, shcho vyznachaiut obsiah i strukturu vytrat obihu na pidpryiemstvi. [Factors that determine the volume and structure of turnover costs at the enterprise]. Naukovyi visnyk Poltavskoho universytetu ekonomiky i torhivli. Seriia: Ekonomichni nauky - Scientific Bulletin of Poltava University of Economics and Trade. Series: Economic Sciences, 2, 197-200. [in Ukrainian].

11. Rudnytskyi, V. S. (2004). Orhanizatsiia pervynnoho obliku ta ekonomichnoho analizu na prykladi pidpryiemstv torhivli. [Organization of primary accounting and economic analysis on the example of trade enterprises]. Kyiv: TsUL. [in Ukrainian]. 
12. Tkachenko, S. O. (2012). Vdoskonalennia systemy optymizatsii vytrat obihu [Improvement of the system of optimization of distribution costs]. Problemy ekonomiky - Problems of economy, 1, 91-95. [in Ukrainian]. URL:https:// www.problecon.com/export_pdf/problems-of-economy-2012-1_0-pages-91_95.pdf (accessed 02 August 2021).

13. Shim, J. K \& Siegel, Joel G. (1996). Metody upravleniya stoimost'yu i analiza zatrat. [Methods of cost management and cost analysis]. Moscow.: Inform.-izd. Dom "Filin". [in Russian]. 